\title{
Structured reporting of metastatic disease for improving communication in comprehensive cancer centers- a feasibility study
}

\author{
J Tesdorff, D Simons, H-P Schlemmer
}

From International Cancer Imaging Society Meeting and 15th Annual Teaching Course (ICIS 2015) London, UK. 5-7 October 2015

\section{Background}

To communicate imaging findings and interpretation precisely and comprehensively within a multidisciplinary treatment team written radiology reports are essential. Structured reporting systems increasingly take advantage of conventional free-form reports. Therefore we developed a visual imaging report chart and evaluated its acceptance by radiologists and oncologists in comprehensive cancer centers.

\section{Method}

Six imaging report charts of representative CT follow-up examination of patients with metastatic melanoma were recorded. Each chart includes a short and focused written text as well as a visual reporting diagram, which is composed of two sections: (1) patient characteristics; and (2) schematic documentation and graphical and pictorial visualization of the radiologic findings including documentation of imaging findings, treatment response according to qualitative or standardised criteria, clinical recommendation and the course of tumour burden. In total 36 reviewers (18 radiologists, 18 clinicians) compared the report charts with the corresponding conventional free-text report by a questionnaire grading their degree of satisfaction by a 10 point Likert-scale. Statistical significance was evaluated by one-way analysis of variance (ANOVA) and Student's t-test.

\section{Results}

Referring oncologists rated improvement of therapy decision making for oncologic patients significantly higher than radiologists $(\mathrm{p}<0.01)$. A significant difference

\footnotetext{
* Correspondence: j.tesdorff@dkfz.de

German Cancer Research Center Heidelberg, Department of Radiology, Germany
} zero/1.0/) applies to the data made available in this article, unless otherwise stated.
Cite this article as: Tesdorff et al:: Structured reporting of metastatic

disease for improving communication in comprehensive cancer centers- a feasibility study. Cancer Imaging 2015 15(Suppl 1):P30.

Submit your next manuscript to BioMed Central and take full advantage of:

- Convenient online submission

- Thorough peer review

- No space constraints or color figure charges

- Immediate publication on acceptance

- Inclusion in PubMed, CAS, Scopus and Google Scholar

- Research which is freely available for redistribution Submit your manuscript at
www.biomedcentral.com/submit C Biomed Central 